\title{
The Component Structure of the Professional Competence of Future Translators
}

\section{Компонентна структура професійної компетентності майбутніх перекладачів}

\section{Ernest Ivashkevych}

Ph.D. in Psychology, Assistant Professor of the Department of Practice of English, Rivne State University of the Humanities, the Translator, Rivne (Ukraine)

ORCID ID: https://orcid.org/0000-0001-7219-1086

Researcher ID: http://www.researcherid.com/rid/F-3865-2019

E-mail: ivashkevych.ee@gmail.com

\section{Ернест Івашкевич}

Кандидат психологічних наук, старший викладач кафедри практики англійської мови, Рівненський державний гуманітарний університет, перекладач, м. Рівне (Україна)

\section{ABSTRACT}

The aim of the article is to distinguish the component structure of the professional competence of future translators.

Methods of the research. As for general scientific methods, the following are used: the method of induction, deduction, analysis and synthesis, comparative and descriptive methods and explanatory ones.

The experimental method was the method of empirical research. During our research we used the methodology "Who am I?" (M. Kuhn, T. McPartland) and the techniques "My way to the profession» and "Pyramid of the professional growth» (developed by M.Yu. Varban and O.B. Starovoitenko and adapted by us for future translators).

Address for correspondence, e-mail: kpnu_lab_ps@ukr.net Copyright: (C) Ivashkevych Ernest

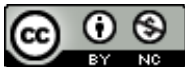

The article is licensed under CC BY-NC 4.0 International

(https://creativecommons.org/licenses/by-nc/4.0/)

C) Ivashkevych Ernest

DOI (article): https://doi.org/10.32626/2227-6246.2021-54.57-77 
DOI: https://doi.org/10.32626/2227-6246.2021-54

2021. випУск 54

The results of the research. In order to determine the structure of the professional competence of a future translator, it is advisable to make some conclusions. In particular, we define professional competence as the implementation in the professional activities of two basic components: professional and technological training, which mean mastering the technology of a specific professional activity (mastering basic and special competencies), and personal component, which is super-professional in nature, but it is one that is necessary for every specialist in order to master the key professionally significant competencies.

Conclusions. So, we consider professional competence as a personal education that contains certain components (or competencies). Such components can be knowledge, skills and abilities, as well as personality traits. Thus, according to our own approach, professional competence includes:

- a special competence, which implies that the specialist has a certain sufficient amount of knowledge in a particular field of the activity, the ability to creatively apply them in various situations related to the solution of theoretical and practical problems and tasks;

- communicative competence, which demonstrates the ability of the person to perceive and express information, to accurately reflect, summarize and justify it. Communicative competence is a necessary prerequisite for interpersonal contacts, dialogue, interaction, which demonstrates the extent to which a person has the rules and techniques of communication;

- social competence, which is expressed by the ability and willingness of the individual to establish and maintain contacts with other people. Social competence is considered to be the most important condition for effective human adaptation to new circumstances of life and professional activity. Its high level helps the specialist to take a leading position in the professional space.

Key words: the professional competence, a special competence, communicative competence, social competence, a specific professional activity, the key professionally significant competencies.

\section{Introduction}

The study of our research of the development of translational competence of students (Гончарук \& Онуррієва, 2018) show that where the teacher puts his/her direct task to develop students with persistent cognitive interests, based on their curiosity, the desire for knowledge, as a rule, the activity (C) Ivashkevych Ernest

DOI (article): https://doi.org/10.32626/2227-6246.2021-54.57-77 
DOI: https://doi.org/10.32626/2227-6246.2021-54

2021. випуск 54

of them in learning always becomes higher, and knowledge is stronger and deeper.

Education without any interest, taken only by force of will, with the help of methods of encouragement and punishment, by the awareness of the obligation to study, can not be a reliable stimulus in teaching; it kills students' desire to learn, generates formalism in learning and does not contribute to the development of cognitive abilities of students, their activity.

One of the important means that promotes the development of students' interests and at the same time activates the cognitive activity of students in the classroom is the skillful disclosure of the contents of their educational material in the process of the activity.

Psychological and pedagogical literature (Івашкевич \& Коваль, 2020) considers the motive as an excitation of the activity associated with the satisfaction of certain needs, a set of internal psychological conditions causing, directing human reality and directing students' actions. Under the educational motives the whole complex of activators of cognitive activity is considered, and the process of implementation of motives in the educational activity is called motivation.

However, as a rule, teachers pay little attention to these questions, and that's why students study diligently, begin their studying of each new topic according to a well-known template: "At the previous lesson we finished studying the topic ..., today we start studying a new topic...»

Such a formal attitude of the teacher to the use of didactic means of stimulating cognitive activity leads to the fact that a large proportion of students do not realize the role of knowledge and studying this or that subject either for the purpose of evaluation or praise, or because of the formal obligation to study (the requirement of parents, the public).

Experienced teachers give questions about the motivation of learning activities and the development of interests, curiosity and cognitive sphere of students with the exceptional

(C) Ivashkevych Ernest

DOI (article): https://doi.org/10.32626/2227-6246.2021-54.57-77 
DOI: https://doi.org/10.32626/2227-6246.2021-54

2021. випуск 54

importance, considering translational competence the most important tool for the development of cognitive activity of students.

It is well-known that the assessment of the significance of the formation of the students' motivation plays an important role. After all we think that the mechanism of the developing of cognitive activity is in two roles - «orienting», which affects the mental activity of students, promotes awareness of the process itself and the understanding of their own knowledge, and «stimulating», which does influence on the expressive-volitional area of the student due to the success of their life and failure.

We drew attention to the fact that the current system of accounting knowledge has a great number of flaws. One of them is that the assessment received by the student is characterized only by the results of their activity (actual knowledge) and is not always the work itself, that is the student makes some efforts. Not all students have the same forces, capabilities, abilities, not all are equally quickly aware and, moreover, not all students remember the material having been studied. Therefore, the outstanding teacher advised all teachers: «Skillfully use the assessment of knowledge - this is a very subtle tool for influencing the student».

Each assessment should describe the student's activity for a certain period. We should take into account the number of responses, additions, the quality of performing a small written essay, etc. To set an objective assessment the teacher examines the student for a certain period, observes his/her attitude to studying at the class, checks the results of home-task.

So, it is necessary to teach students to work in every possible way activating their mental activity. Only such an assessment will be objective, will play the important role in terms of motivating learning activities.

Stimulation of cognitive interests of students comes from various sources, in particular from the content of educational (C) Ivashkevych Ernest

DOI (article): https://doi.org/10.32626/2227-6246.2021-54.57-77 
DOI: https://doi.org/10.32626/2227-6246.2021-54

2021. випуск 54

material, which brings students new, previously unknown information, which causes a sense of surprise before a rich world and how little it is still open to him/her, and how delicious and exciting to know something new at every lesson.

The content of knowledge consists the possibilities to penetrate into all information having been already known, to open new faces in existing knowledge, to view them from a new angle of view and to receive a deep sense of satisfaction from the fact that you now know the subject better, deeper and more thoroughly.

The content of knowledge allows the teachers to penetrate the hideout of science from its inception to modern scientific advancements, discoveries that change the arsenal of scientific tools having been obtained earlier. The awareness of this reinforced interest is displayed in such a way: before the pupil opens the dialectic of phenomena, infinity and eternity of the cognitive process, in which he/she has already risen to a certain level (Mykhalchuk \& Ivashkevych, 2019).

The content of knowledge carries in itself such an important stimulus of cognitive interest as awareness and understanding of a practical role of cognition. The role of science in reality, its importance for social and personal practice, the ability to use scientific knowledge in life - all these and many other things that represent the advent of science in life, in the practice of human activity, greatly raises the prestige of science, knowledge, own knowledge in the eyes of a student and strengthens his/her interest in the eyes of other students and also a teacher.

But the content of knowledge is not the only means of stimulating cognitive interest. Many various incentives for strengthening and forming an interest of the student come from the very activity that generates intellectual and emotional pleasure.

One of the proved means of forming cognitive interests of students is the game. As it already has been noted, the game (C) Ivashkevych Ernest

DOI (article): https://doi.org/10.32626/2227-6246.2021-54.57-77 
DOI: https://doi.org/10.32626/2227-6246.2021-54

2021. випуск 54

is successfully used to stimulate the cognitive activity of students by many teachers-practitioners.

This problem has become widespread nowadays. Just at that time at one of the conferences it was dealt with the problem of improving methods of teaching. We also have to share our experience: «When I began to work as a teacher, it seemed to me that my personality and what I said are for students the most important thing. But very quickly I was convinced that the lesson for many students was just a brief break in their turbulent activity... I was thinking: how to direct the gaming activities of students to the didactic course?"

The severe pedagogical climate, established at a great number of schools in the 60's and 70's, almost left no place for games. But already in the early 70's the situation began somewhat to change. It was also facilitated by the scientific issues (Максименко, Ткач, Литвинчук \& Онуфрієва, 2019; Михальчук \& Онуєфрієва, 2020), in which the problem of the didactic game was emphasized, and the experience of many teachers who were boldly introduced the game into their methodology of teaching different subjects.

In a didactic game, the teaching task appears imperceptibly, not in a vivid way. While playing, the student acquires new knowledge, improves skills and abilities (Mykhalchuk \& Bihunova, 2019). And the main thing is that games always cause a keen interest, the activity for almost all universities. It is almost indifferent here.

In such a way, the aim of the article is to distinguish the component structure of the professional competence of future translators.

\section{Methods of the research}

Taking into account the impotence of the conventional methods of scientific research while dealing with the object of our article, the most substantial part of the methodological base for this research has been developed by us. As for general (c) Ivashkevych Ernest

DOI (article): https://doi.org/10.32626/2227-6246.2021-54.57-77 
DOI: https://doi.org/10.32626/2227-6246.2021-54

2021. випуск 54

scientific methods, such of them as the method of induction, deduction, analysis and synthesis, comparative and descriptive methods and explanatory ones were also used quite successfully.

The experimental research with the purpose to identify the dynamics of the professional development of future translators lasted in 2016-2017. In this research 303 students of experimental and control groups of foreign philology departments were participated:

- experimental groups (150 students):

E1 - 38 students of the 2 nd course of Rivne State University of the Humanities;

E2 - 40 students of the third course of Lviv State University of Life Safety;

E3 - 35 2nd year students of Lesya Ukrainka Eastern European National University;

E4 - 37 students of the third course of Kamianets-Podilskyi National Ivan Ohiienko University;

- control groups (153 students):

K1 - 39 students of the 2nd year of studying of Rivne State University of the Humanities;

K2 - 35 students of the third course of Lviv State University of Life Safety;

K3 - 41 students of the 2nd year of studying of Lesya Ukrainka Eastern European National University;

K4 - 38 students of the third course of Kamianets-Podilskyi National Ivan Ohiienko University named after.

Thus, on the first sub-stage of the experimental research, we studied the level of the readiness of future professionals to perform professional activities. As a methodological tool for the first stage of our research we chose:

1. The Methodology «Who am I?» (Кун \& Макпартленд, 2021).

2. Techniques «My way to the profession» and «Pyramid of the professional growth» (developed by M.Yu. Varban and

C) Ivashkevych Ernest

DOI (article): https://doi.org/10.32626/2227-6246.2021-54.57-77 
DOI: https://doi.org/10.32626/2227-6246.2021-54

2021. випуск 54

O.B. Starovoitenko and adapted by us for future translators) (Варбан, 1998).

\section{Results and their discussion}

According to the criteria of the professional development of future translators we mean a high level of readiness of students to perform translation activities, a high level of professional competence and translation consciousness.

The first sub-stage of the experimental research was aimed at assessing the readiness of students to perform professional activities. The use of our methods made it possible to identify the level of formation of students' motivational, semantic, operational and value readiness to perform translation activities.

Analyzing the teachers' answers to the interview questions, we tried to determine their desire to stimulate selfactualization and the readiness of students to perform professional activities. Asking teachers: "What is your attitude to the readiness of students to perform translation activities and their independent decisions in the process of studying your subject?», it was important for us to determine whether the teacher creates an atmosphere in the classroom that encourages students to perform independent activities.

The questions were addressed to all teachers of the faculties of foreign philology who worked with respondents of the experimental and control groups. The answers were distributed in such a way:

- the largest number of respondents (48.24\%) answered that «they consider the individual approach in teaching to be the main one and always try to use it»;

- $15.63 \%$ of respondents stated that they «wished to create an independent atmosphere in the classroom», but believed that «a high level of understanding of the material must be achieved firstly»;

- approximately the same percentage of teachers $(14.01 \%)$ gave a positive answer and clarified that «the content of the (C) Ivashkevych Ernest

DOI (article): https://doi.org/10.32626/2227-6246.2021-54.57-77 
discipline they had taught involved the implementation of the individual approach»;

- $22.12 \%$ of teachers answered negatively, motivating their answer by the fact that «there were time restrictions during the teaching of academic disciplines, and a great amount of mandatory study material did not allow them to deviate from the given curriculum». In addition, the teachers noted that, unfortunately, students did not have such a stock of knowledge that would allow them to express their opinions on many problems or to be interested in solving educational problems.

During the interview, the teachers outlined the following reasons, which, in their opinion, indicated a lack of creative atmosphere in the classroom: "weak» students; lack of motivation to study; lack of students' understanding of the need to prepare for this subject; lack of desire to work independently, creatively; lack of initiative; lack of necessary knowledge.

Focusing on the answers of the most of the teachers, in the article we concluded that students of all higher educational establishments of foreign philology faculties had opportunities for becoming ready for professional activities, as well as these all teachers were ready to create an atmosphere that was individual for each student at classes.

Thus, three groups of teachers were singled out for self-assessment of their own activities, given their desire to make a creative atmosphere in the classroom. These are teachers with a high level of self-esteem of their own professional activity, situational (average) and low self-esteem, such as:

1. The representatives of the first group try to stimulate students' self-actualization, their readiness for independent translation activities (such answers, as: «I try to stimulate students' initiative», "there is always a desire to work in an atmosphere of freedom of my own professional activity», "all my tasks are more analytical and creative, they must be performed independently», etc.).

(C) Ivashkevych Ernest

DOI (article): https://doi.org/10.32626/2227-6246.2021-54.57-77 
DOI: https://doi.org/10.32626/2227-6246.2021-54

2021. випуск 54

2 . The representatives of the second group (with situational self-esteem) seek to stimulate students only if there are opportunities and perseverance on the part of students (for example: «I encourage students to work independently, but in this experimental group they do not want to work individually» or «a content the discipline I teach is extremely difficult, so students simply cannot work independently»).

3. The third group included teachers with a low self-esteem of their own professional activities. The answers were typical for them: "There is not enough time for individualization of studies», "the course does not involve performing independent creative tasks», "students are not able to do this», "in the curriculums independent work occupies a separate place, the hours are not included into curriculums».

We found that teachers of different disciplines have a very different attitude to the desire of students for self-realization and performance of their own independent activities in the learning process, such as:

\section{- Teachers of special philological disciplines:}

$45.16 \%$ of teachers reported that «not all students wanted to perform professional activities on their own, but those who wanted to perform translation tasks on their own were enough, and they "had led other members of the group»;

$29.17 \%$ of teachers believe that «all students of the Faculty of Foreign Philology are able and try to approach the educational process with interest, great desire, etc., and they are ready to perform their own professional activities»;

only $25.67 \%$ of respondents are skeptical about the readiness of students to perform professional activities in their classes and believe that «a few people are capable of it at all».

- Teachers of general disciplines (of psychological and pedagogical cycle):

$26.18 \%$ of teachers believe that «all students want to work independently and this activity is extremely interesting for them»;

(C) Ivashkevych Ernest

DOI (article): https://doi.org/10.32626/2227-6246.2021-54.57-77 
$73.82 \%$ of teachers say that «only some students are able to perform individual research tasks independently».

- Teachers of disciplines of compulsory cycle, such as subjects that are not directly related to students' translation activities (these are disciplines, «Life Safety», "Philosophy of Science», etc.):

$52.43 \%$ of teachers believe that students «are able to solve the proposed tasks individually»;

$47.57 \%$ of teachers note that «students can only reproduce the educational material».

Thus, we can assume that the understanding of teachers of higher education institutions of students' readiness to perform professional activities, as well as the ability of students to perform individual educational activities may depend on the specifics of the discipline. However, based on the data obtained, we can conclude that about half of teachers (from $40 \%$ to $60 \%$ ) are positive about the capabilities, abilities and possibilities of students. But, on the other hand, according to teachers, the percentage of students (from $15 \%$ to $40 \%$ ) who are only able to engage in different types of activities close to reproductive is quite significant. Thus, students during classes in different disciplines are on an equal footing in terms of stimulating teachers' readiness to perform professional activities. Comparison of the results using Fisher's $\varphi$-test did not show significant differences between students of the experimental and control groups.

At the same time, the obtained results show that teachers have all the opportunities to work with students in this direction, such as: given the attitude of the most students to an individual approach to learning - to use it to develop students' personality, their readiness to perform professional activities.

The students' awareness of the need to update and realize their abilities in terms of translation activity was calculated by the sum of positive and negative answers to questions of our interview. As we can see, a third of the students in each group 
answered negatively. However, such a state may be associated with a desire to move away from the usual, patterned answers, a desire to pay attention to themselves, and to substantiate their points of view originally. However, most students in all groups confirm the need for self-actualization. Comparison of results by Fisher's $\varphi$-criterion did not show significant differences $(F=0.73$ in $\mathrm{E} 1 ; \mathrm{F}=0.71$ in $\mathrm{E} 2 ; \mathrm{F}=0.68$ in $\mathrm{E} 3$; $\mathrm{F}=0.67$ in $\mathrm{E} 1 ; \mathrm{F}=0.75$ in $\mathrm{K} 1 ; \mathrm{F}=0.69$ in $\mathrm{K} 2 ; \mathrm{F}=0.74$ in $\mathrm{K} 3 ; \mathrm{F}=0.73$ in $\mathrm{K} 4$ ) between the students of the experimental and control groups.

When we asked the students who, as a rule, did not demonstrate self-actualization in their learning activities, what was the reason for that situation, then $20.44 \%$ of E1 group respondents, $21.32 \%$ - from E2, 31.44\% - from E3, 32.82\% from $\mathrm{E} 4,25.46 \%$ - in $\mathrm{K} 1,28.04 \%$ - in $\mathrm{K} 2,21.02 \%$ - in $\mathrm{K} 3$ and $28.44 \%$ - in $\mathrm{K} 4$ replied with some insult that teachers mostly listened to what students wanted to express according to that subject, but did not encourage them to be independent and active. Also, almost half of the students in each group said during the interview that only some teachers encouraged their initiative, but specify: "Depending on the discipline». More than $60 \%$ of students in all groups stated that the desire for discussion that leaded to deviation from the topic and the issues that really was interesting for them, as well as the incentive to take classes, was rarely encouraged. About $20 \%$ of the students in each group answered that question: «Teachers tend to ignore the initiative more than encourage it», which, in principle, also did not facilitate the students' readiness for professional activity.

Thus, the results having been obtained indicate that the microclimate at the faculties of foreign philology at various higher education institutions as a whole is favorable for students to be active and to reveal themselves as a creative subject of translation activity.

(C) Ivashkevych Ernest

DOI (article): https://doi.org/10.32626/2227-6246.2021-54.57-77 
To teach students to translate English texts, we proposed them some stories. The translation of students of experimental groups showed a high level of students' translational competence. For example, we proposed the students a text «Newt's Thing with Zinka 8»(Vonnegut, 2009: 10):

«Newt did not tell me who his girl friend was. But about two weeks after he wrote to me everybody in the country knew that her name was Zinka - plain Zinka. Apparently she didn't have a last name.

Zinka was a Ukrainian midget, a dancer with the Borzoi Dance Company. As it happened, Newt saw a performance by that company in Indianapolis, before he went to Cornell. And then the company danced at Cornell. When the Cornell performance was over, little Newt was outside the stage door with a dozen long-stemmed.

The newspapers picked up the story when little Zinka asked for political asylum, and then she and little Newt disappeared.

One week after that, little Zinka presented herself at the Russian Embassy. She said she wanted to go back home.

Newt took shelter in his sister's house in Indianapolis. He gave one brief statement to the press. "It was a private matter», he said. "It was an affair of the heart. I have no regrets. What happened is nobody's business but Zinka's and my own".

One enterprising reporter in Moscow, making inquiries about Zinka among dance people there, made the unkind discovery that Zinka was not, as she claimed, only twenty-three years old.

She was forty-two - old enough to be Newt's mother».

There is a translation, proposed by the student Olga S. of group E1: «Роман Ньюта і Зіки».

Ньют не написав, хто його наречена. Але тижнів через два після його листа вся країна дізналася, що звати її Зіка просто Зіка. Прізвища у неї, напевно, не було.

Зіка була ліліпуткою, балериною іноземного ансамблю. Сталося так, що Ньют потрапив на виступ цього ансамблю в (C) Ivashkevych Ernest

DOI (article): https://doi.org/10.32626/2227-6246.2021-54.57-77 
DOI: https://doi.org/10.32626/2227-6246.2021-54

2021. випуск 54

Індіанаполісі до того, як вступив до Корнелльського університету. А потім ансамбль виступав і в Корнеллі. Коли концерт закінчився, невеликий на зріст Ньют уже стояв біля службового входу з букетом квітів на довгих стеблах.

У газетах ця історія з'явилася, коли Зіка зникла разом із Ньютом.

Але через тиждень після цього Зіка об'явилася у своєму посольстві. Вона заявила, що хоче додому.

Ньют знайшов притулок у будинку своєї сестри в Індіанаполісі. Газетам він дав коротке інтерв'ю: «Це справи особисті... - сказав він. - Серцеві справи. Я ні про що не шкодую. Те, що сталося, нікого не стосується, крім мене і Зіки...».

Один заповзятливий американський репортер, розпитуючи про Зіку декого з балетних, дізнався неприємний факт: Зікі було зовсім не двадцять три роки, як вона говорила. Їй було сорок два - і Ньюту вона годилася в матері».

The next student, also from group E1 proposed such kind of translation:

Частина № 8 «Роман Ньюта і Зіки».

Ньют не написав, хто його наречена. Через два тижні після його листа вся країна нарешті дізналася, що звати їі Зіка - просто Зіка. Прізвища у неї, як видно, не було.

Зіка була українською ліліпуткою, а також красивою танцівницею ансамблю. Одного разу теплим весняним вечором маленький Ньют випадково потрапив на виступ цього ансамблю в Індіанаполісі, до того, як вступив до Корнелльського університету. Потім ансамбль виступав і в Корнеллі. Коли концерт закінчився, маленький Ньют уже стояв біля службового входу з букетом чудових троянд на довгих стеблах.

У газетах ця історія з'явилася, коли крихітка Зіка зникла разом із крихіткою Ньютом.

Але через тиждень після цього крихітка Зіка об'явилася в своєму Російському посольстві. I вона заявила, що дуже хоче додому.

(C) Ivashkevych Ernest

DOI (article): https://doi.org/10.32626/2227-6246.2021-54.57-77 
Крихітка Ньют знайшов притулок у будинку своєї сестри в Індіанаполісі. Газетам він давав коротке та конкретне інтерв'ю: «Наші любовні стосунки - особисті... - сказав він. - Я ні про що не шкодую. Те, що сталося, нікого не стосується, крім мене і моєї коханої Зіки...».

Але одного разу наполегливий репортер дізнався не зовсім хорошу і приємну річ стосовно Зіки від її компаньйонів по танцях. Їй було зовсім не 23 роки, як вона казала всім. Виявилося, що їй було 42 , і вона могла бути маленькому Ньюту мамою» .

In order to determine the structure of the professional competence of a future translator, it is advisable to make some conclusions. In particular, we define professional competence as the implementation in the professional activities of two basic components: professional and technological training, which mean mastering the technology of a specific professional activity (mastering basic and special competencies), and personal component, which is super-professional in nature, but it is one that is necessary for every specialist in order to master the key professionally significant competencies.

\section{Conclusions}

So, we consider professional competence as a personal education that contains certain components (or competencies). Such components can be knowledge, skills and abilities, as well as personality traits. Thus, according to our own approach, professional competence includes:

- a special competence, which implies that the specialist has a certain sufficient amount of knowledge in a particular field of the activity, the ability to creatively apply them in various situations related to the solution of theoretical and practical problems and tasks;

- communicative competence, which demonstrates the ability of the person to perceive and express information, to accurately reflect, summarize and justify it. Communicative

(C) Ivashkevych Ernest

DOI (article): https://doi.org/10.32626/2227-6246.2021-54.57-77 
competence is a necessary prerequisite for interpersonal contacts, dialogue, interaction, which demonstrates the extent to which a person has the rules and techniques of communication;

- social competence, which is expressed by the ability and willingness of the individual to establish and maintain contacts with other people. Social competence is considered to be the most important condition for effective human adaptation to new circumstances of life and professional activity. Its high level helps the specialist to take a leading position in the professional space.

Such kind of the activities as we showed in our article, we think, emphasize on students' interests in the developing their translational competence. Such a program will be proposed by us and we'll describe it in our further publications.

\section{Literature}

Варбан М.Ю. Рефлексия профессионального становления в студенческие годы: дис. ... канд. психол. наук: 19.00.01. Самара, 1998. 181 с.

Гончарук Н., Онуфрієва Л. Психологічний аналіз рівнів побудови комунікативних дій. Психолінгвістика. Психолингвистика. Psycholinguistics, 2018, 24 (1), 97-117. URL : https://doi.org/10.31470/ 2309-1797-2018-24-1-97-117.

Івашкевич Ед., Коваль І. Психологічні принципи організації дедуктивного процесу на уроках англійської мови в закладах середньої освіти. Збірник наукових пращь «Проблели сучасної психологї̈, 2020, 50, 31-52. URL : https://doi.org/10.32626/2227-6246.202050.31-52.

Кун М., Макпартленд Т. Тест «Кто Я?». 2021. URL : vsetesti.ru/424.

Максименко С., Ткач Б., Литвинчук Л., Онуфрієва Л. Нейропсихолінгвістичне дослідження політичних гасел із зовнішньої реклами. Psycholinguistics. Психолінгвістика. Психолингвистика, 2019, 26 (1), 246-264. DOI 10.31470/2309-1797-2019-26-1-246-264. URL : https://psycholing-journal.com/index.php/journal/article/ view/715.

Михальчук Н., Онуфрієва Л. Психологічний аналіз різних типів дискурсу. Збірник наукових праць «Проблели сучасної психологї̈, 2020, 50, 188-210. URL : https://doi.org/10.32626/2227-6246. 2020-50.188-210.

(C) Ivashkevych Ernest

DOI (article): https://doi.org/10.32626/2227-6246.2021-54.57-77 
Mykhalchuk, N., \& Bihunova, S. The verbalization of the concept of «fear» in English and Ukrainian phraseological units. Cognitive Studies Études cognitives, 2019, 11. Варшава (Польща). URL : https://doi. org/10.11649/cs.2043.

Mykhalchuk, N., \& Ivashkevych, E. Psycholinguistic Characteristics of Secondary Predication in Determining the Construction of a Peculiar Picture of the World of a Reader. Психолінгвістика. Психолингвистика. Psycholinguistics, 2019, 25 (1), 215-231. URL : https://doi.10.31470/2309-1797-2019-25-1-215-231.

Vonnegut, Kurt. Cat's Cradle. New York : American Ltd, 2009. 120 p.

\section{References}

Varban, M.Yu. (1998). Refleksiia professionalnogo stanovleniia v studencheskiie gody [The reflection of the professional development in students' years]. Candidate's thesis. Samara [in Russian].

Honcharuk, N., \& Onufriieva, L. (2018). Psykholohichnyi analiz rivniv pobudovy komunikatyvnykh dii [Psychological analysis of the levels of construction of communicative actions]. Psykholinhvistyka. Psikholingvistika. Psycholinguistics - Psycholinguistics. Psycholinguistics. Psycholinguistics, 24 (1), 97-117. Retrieved from https:// doi.10.31470/2309-1797-2018-24-1-97-117 [in Ukrainian].

Ivashkevych, Ed., \& Koval, I. (2020). Psykholohichni pryntsypy orhanizatsii deduktyvnoho protsesu na urokakh anhliiskoi movy v zakladakh serednoi osvity [Psychological Principles of Organization of the Deductive Process at the English Lessons at Secondary Schools]. Zbirnyk naukovykh prats "Problemy suchasnoi psykholohii»-Collection of research papers "Problems of modern psychology», 50, 31-52. Retrieved from https://doi.org/10.32626/2227-6246.2020-50.31-52 [in Ukrainian].

Kuhn, M., \& McPartland, T. (2021). Test «Kto Ya?» [The Methodology "Who am I? »]. Retrieved from vsetesti.ru/424 [in Russian].

Maksymenko, S., Tkach, B., Lytvynchuk, L., \& Onufriieva, L. (2019). Neiropsykholinhvistychne doslidzhennia politychnykh hasel iz zovnishnoi reklamy [A neuropsycholinguistic research of political slogans from outdoor advertising]. Psykholinhvistyka. Psikholingvistika. Psycholinguistics - Psycholinguistics. Psycholinguistics. Psycholinguistics, 26 (1), 246-264. DOI 10.31470/2309-1797-2019-26-1-246264. Retrieved from https://psycholing-journal.com/index.php/ journal/article/view/715 [in Ukrainian].

Mykhalchuk, N., \& Onufriieva, L. (2020). Psykholohichnyi analiz riznykh typiv dyskursu [Psychological Analysis of Different Types of Dis-

(C) Ivashkevych Ernest

DOI (article): https://doi.org/10.32626/2227-6246.2021-54.57-77 
DOI: https://doi.org/10.32626/2227-6246.2021-54

2021. випуск 54

course]. Zbirnyk naukovykh prats «Problemy suchasnoi psykholohii» - Collection of research papers "Problems of modern psychology», 50, 188-210. Retrieved from https://doi.org/10.32626/22276246.2020-50.188-210 [in Ukrainian].

Mykhalchuk, N., \& Bihunova, S. (2019). The verbalization of the concept of «fear» in English and Ukrainian phraseological units. Cognitive Studies | Études cognitives, 19, 11. Warsaw (Poland). Retrieved from https://doi.org/10.11649/cs.2043.

Mykhalchuk, N., \& Ivashkevych, E. (2019). Psycholinguistic Characteristics of Secondary Predication in Determining the Construction of a Peculiar Picture of the World of a Reader. Психолінгвістика. Психолингвистика. Psycholinguistics - Psycholinguistics. Psycholinguistics. Psycholinguistics, 25 (1), 215-231. Retrieved from https://doi.10.31470/2309-1797-2019-25-1-215-231.

Vonnegut, Kurt (2009). Cat's Cradle. New York : American Ltd.

Івашкевич Ернест. Компонентна структура професійної компетентності майбутніх перекладачів

\section{АНОТАЦІЯ}

Мета статmі - виокремити компонентну структуру професійної компетентності майбутніх перекладачів.

у роботі використано такі загальнонаукові методи дослідження: індукція, дедукція, аналіз і синтез, порівняння й опис, обгрунтування mошио.

Експериментальним методом був метод проведення емпіричного дослідження. У якості методологічного інструментарію для першого етапу дослідження нами було обрано методику "Хто Я?» (М. Кун, T. Макпартленд) і техніки «Мій шлях у профресію» та «Піраміда профресійного зростання» (розроблені М.Ю. Варбан та О.Б. Старовойтенко й адаптовані нами для майбутніх перекладачів).

Результати дослідження. Визначено структуру професійної компетентності майбутнього перекладача. Ми визначаємо професійну компетентність як реалізацію в професійній діяльності двох базових компонентів: професійно-технологічної підготовленості, що має на увазі оволодіння фрахівцем технологіями здійснення конкретної професійної діяльності (оволодіння базовими і спеціальними компетентностями), й особистісного компонента, що вирізняється надпрофесійним характе(C) Ivashkevych Ernest

DOI (article): https://doi.org/10.32626/2227-6246.2021-54.57-77 
ром, але є таким, який необхідний кожному фахівцеві з метою оволодіння ним ключовими професійно значущими компетентностями.

Висновки. Доведено, що профресійну компетентність слід розглядати як особистісне утворення, що вміщує певні компоненти (або компетенції). Такими компонентами можуть бути знання, уміння і навички, а також властивості особистості. Так, згідно з цим підходом професійна компетентність включає:

- спеціальну компетентність, що передбачає наявність у фахівця певного достатнього обсягу знань у конкретній галузі діяльності, вміння їх творчо застосовувати в різноманітних ситуаціях, пов'язаних із розв'язанням теоретичних і практичних завдань і задач;

- комунікативну компетентність, що демонструє здатність індивіда сприймати та висловлювати інформацію, ії достовірно відображати, підсумовувати й обгрунтовувати. Комунікативна компетентність є необхідною передумовою для здійснення міжособистісних контактів, діалогу, взаємодії, яка демонструє, наскільки людина володіє правилами і прийомами спілкування;

- соціальну компетентність, що виражається в здатності й готовності особистості встановлювати та підтримувати контакти з іншими людьми. Сочіальна компетентність вважається найважливішою умовою ефективної адаптації людини до нових обставин життя і профресійної діяльності. її високий рівень допомагає фрахівцеві зайняти лідерські позиції в професійному просторі.

Ключові слова: професійна компетентність, спеціальна компетентність, комунікативна компетентність, соціальна компетентність, специфрічна професійна діяльність, ключові професійно значущі компетентності.

\section{Ивашкевич Эдуард. Компонентная структура профессиональной ком- петентности будущих переводчиков}

\section{АННОТАЦИЯ}

Цель статьи - выделить компонентную структуру профессиональной компетентности будущих переводчиков.

Из совокупности основных научных методов были использованы такие методы исследования: индукция, дедукция, анализ и синтез, сравнение и описание, метод обоснования.

(C) Ivashkevych Ernest

DOI (article): https://doi.org/10.32626/2227-6246.2021-54.57-77 
Экспериментальным методом был метод проведения эмпирического исследования. В качестве методологического инструментария для первого этапа исследования нами были отобраны методика "Кто Я?» (М. Кун, Т. Макпартленд) и техники «Мой путь в профессию» и «Пирамида профессионального роста» (разработаны М.Ю. Варбан и Е.Б. Старовойтенко и адаптированы нами для будущих переводчиков).

Результаты исследования. Определена структура профессиональной компетентности будущего переводчика. Мы определяем профессиональную компетентность как личностное новообразование, которое позволяет специалисту реализовать в профессиональной деятельности два базовых компонента: профессионально-технологическую готовность, что подразумевает овладение специалистом технологиями осуществления конкретной профессиональной деятельности (овладение базовыми и специальными компетентностями), и личностный компонент, который отличается надпрофессиональным характером, то есть таким, который необходим кандому специалисту с целью овладения им ключевыми профессионально значимыми компетентностями.

Выводы. Доказано, что наиболее содержательным является подход, позволяющий рассматривать профессиональную компетентность как личностное новообразование, которое содержит определенные компоненты (или компетентности). Такими компонентами могут быть знания, умения и навыки, а также свойства личности. Так, в соответствии с данным подходом профессиональная компетентность включает:

- специальную компетентность, которая предполагает наличие у специалиста определенного достаточного объема знаний в конкретной области деятельности, умение их творчески применять в различных ситуациях, связанных с решением теоретических и практических заданий и задач;

- коммуникативную компетентность, которая демонстрирует способность индивида воспринимать и излагать информацию, ее достоверно отражать, суммировать и обосновывать. Коммуникативная компетентность является необходимым условием для осуществления межличностных контактов, диалога, взаимодействия, она демонстрирует, в какой мере человек владеет правилами и приемами общения;

- социальную компетентность, которая выражается в способности и готовности личности устанавливать и поддерживать контакты с другими людьми. Социальная компетентность считается нами () Ivashkevych Ernest

DOI (article): https://doi.org/10.32626/2227-6246.2021-54.57-77 
DOI: https://doi.org/10.32626/2227-6246.2021-54

2021. ВИПУСК 54

важнейшим условием эфрфективной адаптации человека к новым обстоятельствам жизни и профессиональной деятельности. Ее высокий уровень помогает специалисту занять лидерские позиции в профессиональном пространстве.

Ключевые слова: профессиональная компетентность, специальная компетентность, коммуникативная компетентность, социальная компетентность, специфическая профессиональная деятельность, ключевые профессионально значимые компетентности.

Original manuscript received July 12, 2021

Revised manuscript accepted August 28, 2021

(C) Ivashkevych Ernest

DOI (article): https://doi.org/10.32626/2227-6246.2021-54.57-77 